Archimer, archive institutionnelle de l'ffremer Vol. 83, Issues 2-3, February 2007, Pages 123-132 http://www.ifremer.fr/docelec/ http://dx.doi.org/ 0.1016/j.fishres.2006.09.002 (c) 2006 Elsevier B.V. All rights reserved

\title{
Assessment of sea bass (Dicentrarchus labrax, L.) stock delimitation in the Bay of Biscay and the English Channel based on mark-recapture and genetic data
}

\author{
M. Fritsch ${ }^{1^{\star}}$, Y. Morizur $^{1}$, E. Lambert ${ }^{2}$, F. Bonhomme $^{2}$ \& B. Guinand ${ }^{2}$ \\ ${ }^{1}$ : IFREMER, Centre de Brest - Département Sciences et Technologies Halieutiques - Laboratoire Unité des \\ Populations et des Peuplements - BP 70, 29280 Plouzané, France \\ 2 : Université Montpellier II - IFREMER - CNRS UMR 5171 - Laboratoire Génome, Populations, Interactions, \\ Adaptation, Station Méditerranéenne de l'Environnement Littoral, 1 Quai de la Daurade, 34200 Sète, France \\ * corresponding author : email: manonfritsch@yahoo.fr
}

\begin{abstract}
:
Sea bass (Dicentrarchus labrax) fisheries are becoming increasingly abundant along eastern Atlantic coastlines, especially in the ICES sub-areas IV, VII and VIII, but they are still not being managed by the European Union TAC (Total Allowed Catches) system. Scientific information about these sea bass stocks is limited, but the fishery is currently managed or modelled based upon these data, separated into the ICES divisions. Clearly, failure to manage satisfactorily the fishery may lead to a decline in stocks. We therefore investigated the structure of Atlantic sea bass populations at eight microsatellite loci in the Bay of Biscay and the English Channel and, additionally, at five selected loci in Ireland and Scotland. Genetic data showed no significant population differentiation between the Bay of Biscay and the English Channel samples, either for juvenile or adult individuals, indicating substantial gene flow. These results contrast with tag-recapture data that indicated restricted movements of individuals within the Bay of Biscay or the English Channel, and little exchange between them. These apparently contradictory genetic and tag-recapture results can be reconciled by various aspects of sea bass biology, factors that should be considered in stock management. Furthermore, the results indicate some local genetic differentiation in the Irish sample when compared to other samples, possibly indicating a complex population structure of sea bass around the British Isles. This point should be further investigated, but results clearly indicate that sea bass stock management should not be based only upon the currently recognized ICES divisions.
\end{abstract}

Keywords: Dicentrarchus labrax; Mark-recapture; Tagging; Microsatellite loci; Population structure 


\section{Introduction}

The sea bass, Dicentrarchus labrax (L., 1758), is a demersal species found throughout the Mediterranean Sea and the Eastern Atlantic, ranging approximately from Southern Morocco to the Norwegian coastlines. Currently, natural populations of sea bass are not managed with the European Union TAC (Total Allowed Catches) system, although they are exploited by several fisheries in the European countries, principally France, UK, and Spain. For example, the largest bass fishery is in France, where the species is targeted throughout the year by professional liners, and seasonally by trawlers, gillnetters and recreational anglers. It is the fifth species in landed value in spite of a relatively low total catch of about 4000 tonnes per year. A lack of quota management partly explains the relatively low scientific contribution to sea bass stock assessment. Management of the fisheries is, however, now required because of the increasing interest in this species by both recreational and commercial fishermen. The main fishing areas in European waters are the Mediterranean Sea and, in the Eastern Atlantic, the ICES (International Council for the Exploitation of the Sea) Sub-areas IV, VII and VIII. Indeed, the bulk of the catch comes from the area between the Bay of Biscay, the Irish Sea and the North Sea. In this region, the wide dispersion of "adolescent" sea bass as they migrate from nursery areas to join spawning stocks, and of adults between summer and winter areas provide little evidence for the existence of independent biological populations. Nevertheless, tagging studies carried out around the British Isles (Kennedy \& Fitzmaurice, 1972; Holden \& Williams, 1974; Kelley, 1979; Pawson et al., 1987) and the seasonal distribution of the fisheries suggest that separate populations may exist.

Although numerous population genetics studies have been carried out with sea bass, they have focussed upon Mediterranean populations (e.g. Patarnello et al., 1993; Allegrucci et al., 1997; Caccone et al., 1997; Bahri-Sfar et al., 2000), with less attention paid to Atlantic populations (Castilho \& McAndrew, 1998; Naciri et al., 1999; Bonhomme et al., 2002). As for numerous other marine species, the most striking feature in the genetic structure of sea bass populations is the division between Atlantic and Mediterranean populations (Naciri et al., 1999). While the Mediterranean Sea appears to be genetically structured into several subbasins (Patarnello et al., 1993; Bahri-Sfar et al., 2000; see also Garcia De León et al., 1997), Atlantic populations were genetically homogeneous over wide areas, indicating high levels of gene flow (e.g. Bonhomme et al., 2002). Despite such knowledge, further data about the genetic structure of sea bass in the Atlantic is important for several reasons. Firstly, few Atlantic populations have been screened for both allozymes (Castilho \& McAndrew, 1998) and microsatellites (Naciri et al., 1999; Bonhomme et al., 2002), but these report slightly contrasting results (i.e. no genetic differentiation when using microsatellite loci vs low but significant differentiation with allozymes). Such previous studies were also mainly restricted to Moroccan and Portuguese populations, together with one English Channel and one North Sea population. As a major objective of fisheries genetics is the identification of discrete populations or groups with more or less restricted gene flow (reviewed in, e.g., Carvalho \& Hauser, 1995; Hauser \& Ward, 1998), stock delimitation - if any - among Atlantic sea bass populations should be investigated more closely using genetic tools. Furthermore, the previous studies were restricted to analysis of population or stock differentiation and they did not consider other biological aspects that can structure genetic data. In particular, studies have considered either juveniles (Castilho \& McAndrew, 1998) or adults (Naciri et al., 1999), but not different life-stages concomitantly. As many so-called populations of marine fish may consist of amalgamations of geographic subpopulations or spawning components with a variable degree of segregation (e.g. McQuinn, 1997; Smedbol \& Stephenson, 2001), this can lead to processes that may partly bias the picture of genetic structure in Atlantic sea bass (for 
instance, are juveniles representative of the local adult population?). Failure by fishery managers to account for stock complexity and composition may lead to depletion of particular components, with unknown ecological consequences (e.g. Stephenson, 1999). This can critically affect the long-term stability and sustainability of the entire stock. Finally, and most importantly, insights from genetic data in sea bass have not been compared to quantitative methods that also provide pictures of the dispersal of individuals, such as mark-recapture methods. Hence, a sustainable management scheme for sea bass cannot be implemented without accurate stock identification, for which genetic and tagging studies provide essential and complementary information (Slatkin, 1985; Rousset, 2001; Adams \& Hutchings, 2003; Vandewoestijne \& Baguette, 2004; Palumbi, 2004).

In this study we investigated genetic variation at microsatellite loci for a set of Atlantic populations of adult and juvenile sea bass, with a primary focus on Bay of Biscay and English Channel populations, but also on Irish and Scottish populations. We contrasted results obtained from this genetic analysis with those from a three year mark-recapture study on adult populations in the Bay of Biscay and English Channel.

\section{Materials and Methods}

\subsection{ICES divisions for sea bass management}

Recognised divisions (A to F) for sea bass management are given in Fig. 1, together with positions of samples that were used in genetic analysis.

\subsection{Mark-recapture/tagging studies}

From December 2001 until March 2004, around 6100 sea bass were tagged in the Bay of Biscay and the English Channel. Tagging campaigns, organised by the Département Sciences et Technologies Halieutiques of IFREMER (Institut Français pour la Recherche et l'Exploration de la Mer Brest Centre, France) with the collaboration of the Oceanic Development company, were conducted on commercial pelagic trawlers. These fishing boats target concentrations of adult sea bass in winter, during the breeding season . Before starting the campaigns, a feasibility study managed by scientists from both IFREMER and CEFAS (Centre for Environment, Fisheries and Aquaculture Science; Lowestoft, United Kingdom) in March 2000 proved that this the process appropriate for tagging sea bass. Table 1 indicates release data of bass tagging campaigns.

After each trawl tow, the most healthy fish are tagged on board with large-size internal/external abdominal anchor tag ("New York", Hallprint PTY Ldt., Holden Hill, South Australia). These tags consist of $105 \mathrm{~mm}$ long yellow coloured streamer linked to a "T - bar" insert anchor. They allow the fish freedom of movement and are relatively quick and easy to apply. They have good retentive properties and have been used successfully in previous studies (Pawson et al., 1987). Moreover, this type of tag was well accepted by sea bass in a preliminary test conducted on 3 year-old cultured fish (Y. Morizur, unpublished data). Fish for tagging were laid on a piece of wet cloth in order to manipulate them without damage. They were measured (total length from nose to end of caudal fin), tagged and then released after recovery in a tank of refreshed sea-water. Before applying the tag, a small vertical incision into the peritoneum was made with a scalpel, one or two $\mathrm{cm}$ above anus. The " $\mathrm{T}-$ bar" was inserted to the anterior, to avoid contact with the internal organs. Although their age was not precisely known, tagged fish were assumed to be adult and sexually mature by their presence in the spawning grounds at that season.

Capture and release areas were determined according to trawlers' log books, where all tow positions were registered (Table 1). Tags carried a unique serial number and a 
message printed in English and French asking recapture details (tag number, place and date of capture, size of fish) to be returned to CEFAS or IFREMER. Local and national fishermens committees relevant to the tagging campaign were informed by letter. Moreover, posters were distributed in fish markets, and an article was published in a professional fishing newspaper (Le Marin) and in a recreational fishing magazine ("La Pêche en Mer”).

\subsection{Genetic analysis}

A piece of a dorsal fin was collected on each fish for populations listed in Table 2, and individually stored in ethanol $95^{\circ}$ until analyses. In the laboratory, sea bass DNA was extracted from muscle using either the QIAamp ${ }^{\circledR}$ DNA Mini Kit (QIAGEN) or using standard phenol-chloroform-isoamylic alcohol method (25:24:1).

Five (all samples) or eight (juveniles samples, and Bay of Biscay and Western English Channel adult samples) microsatellite loci were used in this study. More loci were analysed in latter populations because of individual assignment procedure (see below). Loci used in this study are listed in Table 3. Except for locus Dla-47 (Ciftci et al., 2002) for which information is not available, retained loci were a priori not linked together in pairwise relationships (Chistiakov et al., 2004).

Individual PCR amplifications at each locus were carried out in $20 \mu$ reaction mixture containing $1 \mu \mathrm{l}$ DNA template, $0.5 \mu \mathrm{M}$ of each primer (one primer per set were labelled in 5' end with either fluorochrome TAMRA or 6-FAM (Eurogentec, Strasbourg, France)) (Table 3), $1.5 \mathrm{mM} \mathrm{MgCl} 2$ (Promega, Madison WI, USA), $50 \mu \mathrm{M}$ of each dNTP, and 0.1 U Taq polymerase (Promega, Madison WI, USA). After initial denaturation (2 to $10 \mathrm{~min}$ ) at $96^{\circ} \mathrm{C}$, amplification conditions were 30 cycles of denaturation at $94^{\circ} \mathrm{C}$ for $1 \mathrm{~min}$, annealing at specific temperature, and extension at $72^{\circ} \mathrm{C}$ for $1 \mathrm{~min}$ (details in Table 3). A final extension step of $10 \mathrm{mn}$ was carried out for all microsatellite loci at the end of PCR reaction. Amplification products were used undiluted and mixed with half volume of formamide loading dye (95\% formamide, $20 \mathrm{mM}$ EDTA, 0.05\% xylene cyanol and 0.05\% bromophenol blue), denatured at $94^{\circ} \mathrm{C}$ for $5 \mathrm{~min}$. Up to five, but generally three microlitres of this mixture were loaded into $6 \%$ denaturing polyacrylamide gel and ran using $1 \mathrm{X}$ TBE buffer at $50 \mathrm{~W}$ for 3 hours. The gels were then laser-scanned and the fluorescent bands were visualised in an FMBio II fluorescence imaging apparatus (Hitachi Instruments, San José CA, USA). Once calibration of the size of several alleles were performed using commercial molecules of known fragment size, several individuals of known genotypes were used as additional allelesize standards on each gel to calibrate size of observed alleles.

Number of alleles per locus and per population, expected $\left(\mathrm{H}_{\mathrm{e}}\right)$ and unbiased observed $\left(\mathrm{H}_{\mathrm{obs}}\right)$ gene diversities were estimated from raw genotypic data using Genetix v.4.03 (Belkhir et al., 2000; available at http://www.univ-montp2.fr/ genetix/). As sample size varies between locations, allelic richness may vary greatly from one sample to another (i.e. small samples generally have a lower number of alleles than larger samples). Direct and simple comparison of allelic richness is not straightforward. Hence, allelic richness was standardised to that of the smallest sample over populations and over loci using a 'rarefaction method' (details in Petit et al. 1998). Basically, such a standardisation provides one estimation of the mean number of alleles for a given sample size (i.e. the lowest observed sample size at a given locus). Leberg (2002) proved that this method provides an unbiased estimate of allelic richness for a given sample size, allowing comparisons across samples. Estimations of standardised allelic richness of each sample were carried out using the program CONTRIB developed by Petit et al. (1998), available at http://www.pierroton.inra.fr/genetics/labo/Software/Contrib/. Once standardised, such estimations of allelic richness were compared using t-tests. Deviations from Hardy-Weinberg expectations within samples were investigated using Genetix v.4.03 by estimating Weir \& 
Cockerham's (1984) $\underline{\mathrm{f}}$. Test of the null hypothesis of no significant departure from HardyWeinberg expectations $(\underline{f}=0)$ was carried by randomly permutating alleles from the original matrix of genotypes using the appropriate procedure in Genetix v.4.03. When locus depart from Hardy-Weinberg equilibrium could be due to null alleles or scoring errors such as allele drop out or stuttering. Specific causes explaining why loci were out of Hardy-Weinberg expectations were analysed using the software Microchecker (Van Oosterhout et al. 2004; available at http://www.microchecker.hull.ac.uk). Linkage disequilibrium between pairs of nuclear loci (i.e. nonrandom associations of particular genotypes) according to the method of Weir (1979) were tested with Genetix v. 4.03. Finally, levels of pairwise population differentiation were investigated using Weir \& Cockerham's (1984) $\underline{\theta}$, an estimator of Wright's (1951) $\underline{F}_{s t}$, also using Genetix v.4.03. Critical significance levels for multiple testing were corrected using a sequential Bonferroni procedure (Holm, 1979).

\section{Results}

\subsection{Mark recapture studies}

Between March 2000 and March 2004, a total of 1968 sea bass were tagged in winter offshore fisheries in the English Channel (VIId,e,h) and a further 169 bass in the Celtic Sea (VIIa,f) (total: 2137). Between December 2001 and February 2004, 3977 bass were tagged on the spawning grounds of the Bay of Biscay (VIIIa,b) (Table 4).

Up until the end of April 2005, a total of 69 recaptures of tagged bass have been reported with respectively 24, 1, 28 and 16 tagging in Divisions VIIe, VIIf, VIIIa and VIIIb (Table 4; Fig. 1). Most of the recaptures (59.4\%; 41 out of 69) occurred one or two months after tagging (Fig. 3). Recaptures became less frequent as time from tagging increased: these were regularly reported up to the seventh month, but recaptures became very scarce after the eighth month.

During the first month after tagging, sea bass were chiefly recaptured with trawlers in the same ICES Statistical Rectangle where they were tagged, or in a contiguous one. This could mean that fish stay at least one month on spawning grounds. Recaptures during the second month after tagging were mainly outside the offshore release area $(80 \%$; 12 fish out 15), and from gears other than trawlers (principally lines and longlines, but nets too). Therefore, sea bass returned to the coasts as soon as their spawning period finished, where they were targeted by inshore fisheries. This trend was confirmed between the third and the seventh month after tagging, the period corresponding to recaptures between April and September (30.4\%; 21 fish out 69), because tagged sea bass were only caught by inshore fisheries in coastal summer feeding areas.

Most of the 25 recaptures of sea bass tagged in the English Channel and in the Celtic Sea tended towards the English coasts, namely the south of the west coast $(16 \%$; 4 recaptures), the north of the release area in the western Channel (48\%; 12 recaptures), and the east of the south coast until the North Sea (16\%; 4 recaptures) (Fig. 1). For the other recaptures, 2 tagged bass (8\%) were caught in the Channel Islands, and only $3(12 \%)$ in the French inshore areas: in the north coast of Brittany, near Cherbourg and in the Bay of Biscay (as far as the Adour estuary) (Fig. 2).

In the Bay of Biscay, 44 bass were caught by trawlers on winter spawning grounds (45.5\%; 20 fish) or by inshore fisheries on summer feeding areas (54.5\%; 24 fish). Inshore recaptures cover all the coasts from north to south of the Bay (Fig. 2). Fish tagged on division VIIIa were chiefly caught in the north part of the Bay between La Rochelle and Lorient, and recaptures from those tagged on division VIIIb were mainly located in the south part of the Bay, near Bordeaux and further south. Thus, a connection can be made between the spawning 
ground location and the part of the Bay of Biscay where bass migrate in summer. However, exceptions were noted and more data are required to extend our knowledge of bass movements in the whole Bay. At the present time, we can only assume that most fish found on offshore spawning grounds settle all along the Bay of Biscay coasts in summer.

Recaptures show that fishes remain most of the time in their tagging basin. But three out 69 recaptures (around 4\% of the total) revealed communications between the English Channel or the Celtic Sea and the Bay of Biscay. Indeed, one fish tagged in the Celtic Sea was found in the Adour estuary, and two fish tagged in the Bay of Biscay were recaptured near Cherbourg and Boulogne (Fig. 2).

\subsection{Genetic population structure}

When considering data obtained from the set of eight microsatellite loci (Bay of Biscay, Biarritz, La Rochelle, West Channel, Saint-Malo, and Calais; Table 5), observed gene diversities were homogeneous ranging from $\mathrm{H}_{\mathrm{obs}}=0.752$ for the Calais population to $\mathrm{H}_{\mathrm{obs}}=$ 0.798 for the La Rochelle population. No significant linkage disequilibrium was found among loci across populations. As sample sizes varied greatly, the number of alleles $(\underline{k})$ was very different from one population to an other (Table 5). For each locus, estimated standardized richness $\left(\underline{k}_{e s t}\right)$ was not significantly different among the samples (t-tests; all $\underline{p}>0.05$ ). As measured by observed multilocus values of $\underline{f}$, no global departure from Hardy-Weinberg equilibrium was recorded (Table 5), despite reported values for the locus DLA0006 that did not match Hardy-Weinberg equilibrium in most populations ( $\underline{f}$ ranging from 0.156 to 0.581 ; $\mathrm{p}$ $<0.05$ after Bonferroni correction; Table 5), except for the La Rochelle population ( $\underline{f}=0.073$; bootstrap 95\% CI $=[-0.155,0.275])$. According to the software Microchecker, the most probable cause of significant positive values of $\underline{f}$ indicated presence of one null allele at this locus, leading to observed deficits of heterozygotes in most samples. As such a deficit did not influence the outcome of multilocus $\underline{f}$ (i.e. overall observed Hardy-Weinberg equilibrium) in 4 of 6 populations in the eight loci data set, we retained it in subsequent analyses. Exclusion of locus DLA0006 did not influence the estimation of population differentiation reported hereafter (results not shown).

The overall level of genetic differentiation was low and not significant among those populations screened for eight loci $(\underline{\theta}=0.001$; bootstrap 95\% CI $=[-0.0006,0.0025])$. Observed estimates of pairwise genetic differentiation among samples were uniformly low and not significant, except for the West Channel / Saint-Malo comparison (Table 6). However, this significance was lost following correction for multiple comparisons. Overall, results indicated very little structuring along the western coasts of France, and no clear differentiation between adults and juveniles.

When considering data sets with eight populations, i.e. including the Ireland $\left(\mathrm{H}_{\mathrm{obs}}=\right.$ 0.744; $\underline{\mathrm{f}}=0.01$, NS) and Scotland $\left(\mathrm{H}_{\mathrm{obs}}=0.753 ; \underline{\mathrm{f}}=-0.004\right.$, NS) samples, but genotyped at only five loci (as locus DLA0006 is not considered in this data set, no departure from HardyWeinberg equilibrium was recorded at those locations, Table 5), overall genetic differentiation was low but significant $(\underline{\theta}=0.002$; $\mathrm{p}<0.05$; bootstrap 95\% CI $=[0.0002$, 0.0043]). Slightly more population structuring was observed in pairwise comparisons of populations, especially between the Irish and the other populations (Table 7). All significant values were, however, lost following correction for multiple comparisons. Such corrections should, nonetheless, be viewed with caution in this case because the most significant values concerned the Irish population. That is, statistically, if significant results were randomly distributed over the distance matrix (Table 7), each pair would have 8 (the number of populations) chances over 28 (the number of comparisons) to be significant. As we have 7 pairs/comparison for each population, under the null hypothesis, each population should have 2 significant pairwise comparisons $([7 \times 8] / 28=2)$ in average. Five significant comparisons 
were reported for the Irish sample (Table 7), and so this result would appear as very unlikely (see Discussion).

\section{Discussion}

Reliable knowledge of population structures, and particularly all information that concerns identification and distribution of separate stocks, is required to manage fisheries. Nowadays, modelling of sea bass stocks are based on data dissociated per ICES division (ICES, 2002, 2003, 2004). Such arbitrary partitions do not necessarily, however, correspond to a biological reality and so could alter model results and bias analyses. As far as is known, the present study is the first to combine tagging and microsatellite genetic data in an analysis of fine-scale sea bass population structure. It could, therefore, contribute to improving prospective modelling for sea bass stock management.

Mark-recapture studies of sea bass in Bay of Biscay, English Channel and Celtic Sea indicate that low percentages of tagged fish are recaptured $(1.1 \%$ in this study; $3.7 \%$ in the study from Pickett et al., 2004, rarely more than $10 \%$ in other studies, e.g. Kelley, 1979). As a consequence, movements of fish revealed by tagging rely upon a few individuals and can only be extrapolated with caution to the whole population. Moreover, interpretation of data is limited because most individuals were recaptured in the first month or the first two months after tagging (Fig. 2). This indicates that adult sea bass remain at least one month on winter spawning grounds before moving towards their summer feeding areas. This period is too brief to clearly define what might constitute the home range of sea bass during the majority of its lifetime. Although the percentages of recapture were low, results do suggest little migration across areas by individuals: tagging and recapture basins were the same in most cases. From a biological point of view this could suggest that two populations exist: one in the Bay of Biscay, the second in the English Channel and the region of the Celtic Sea around the United Kingdom's coasts. However, communication between these two basins cannot be ignored, even if they seem to be low. Indeed, 4.3\% of this study's tagged bass (3 out 69 recaptures) moved from one tagging basin to the other. Some other studies have indicated that sea bass migrate from the Channel to the Bay of Biscay. For example, Pickett et al. (2004) note that one sea bass tagged in southeast England was recaptured in western France. Similarly, Pawson et al. (1987) note that three bass moved from English coasts to the Bay of Biscay. In the present study, among the three individuals that were recaptured outside the basin where they were tagged (Fig. 2), one of them was tagged in April in the Celtic Sea and then caught in May close the Adour estuary (Fig. 2); the other two tagged in January in the Bay of Biscay were recaptured after about five months in the English Channel. As annual migrations in sea bass occur from winter southern spawning areas to northern summer feeding grounds, the two latter individuals clearly match the expected pattern. The remaining individual does not match this model, indicating that long-distance movements can be accomplished quite rapidly.

Genetic results obtained through the analysis of eight microsatellite locus in the same area as the tagging study indicated lack of genetic differentiation among individuals inhabiting the Bay of Biscay and the English Channel (Table 6, see also Table 7). Results from assignment tests further indicated large assignment error rates for each juvenile sample, ranging from about 34\% for La Rochelle individuals to 74\% for Saint-Malo individuals. More generally, results demonstrated that less juveniles were assigned to English Channel baseline (adult) population compared to the Bay of Biscay baseline but, most importantly, the number of individuals assigned to baselines with intermediate probabilities (e.g., $0.15<\mathrm{p}<0.85$ ) is rather high (Fig. 3). This indicates an inability to assign most individual to one group or the other because of genetic homogeneity. Lack of genetic differentiation between the Bay of 
Biscay and the English Channel population as recorded at eight microsatellite loci for both juveniles and adults is not totally surprising, and was already indicated by Naciri et al. (1999) and Bonhomme et al. (2002) adult fish only. Multilocus data also indicated no significant departure from Hardy-Weinberg equilibrium for all samples when correction for multiple tests is applied, despite significant observed values of $\underline{f}$ at locus DLA0006 (Table 5). Such a locus should probably have a null allele that partly bias observed values of $\underline{f}$ as already observed in Naciri et al. (1999) for another microsatellite locus. Thus, at first sight, tagging and genetic results are contradictory. On the one hand, tagging results distinguish two entities in the Bay of Biscay and in the English Channel while, on the other hand, genetic data show homogeneity between these entities (Table 6). However, the migrations of a few bass from a basin to the other, as proved by tagging, could explain this paradox. Indeed, the number of migrants between basins might easily be sufficiently large to promote genetic homogeneity through successive generations for bass inhabiting the (Eastern) Channel and the Bay of Biscay. Preferential assignment of English Channel juveniles from Calais and Saint-Malo to adult (baseline) samples from the Bay of Biscay might also indicate such exchanges (Fig. 4), even though this conclusion should be considered with caution as it might also result from a statistical artefact. As the baseline adult population in the Western Channel had a lower sample size than in the Bay of Biscay, allele frequency distributions are poorly assessed and assignment results for juveniles from Calais and Saint-Malo could be biased. This point should be investigated further.

At a broader scale and with five microsatellite loci only, genetic differentiation was quite low, but significant $(\underline{\theta}=0.002 ; p<0.05)$. Our results suggest that Irish and Scottish populations could be slightly differentiated from the Bay of Biscay and Channel populations (Table 7). This is especially true for the Ireland population that was significantly differentiated from most other populations. The significance of genetic differentiation estimates was lost when considering correction for multiple tests, but Table 7 did not show a random structure, significant results being predominantly associated with the Irish population. We should be very careful about this finding, because the Ireland, but also Scotland samples were limited, showing more similar standardised allelic richness and genetic diversities than other samples (Table 5). This could easily lead to overestimation of genetic differentiation between pairs of samples, thus leading to a pattern where significant results could be associated with a peculiar sample. However, in such a case, it is difficult to understand why the small Scottish sample did not show similar patterns of genetic differentiation to those of the Ireland sample. More samples and individuals should be genotyped to correctly assess this pattern of genetic differentiation. Nevertheless, several lines of evidence might suggest than differentiation of the Ireland sample is not unlikely. Among all the sea bass tagged on the West English coasts, none have been ecovered on the Irish coasts (Kelley, 1979; Pickett \& Pawson, 1994). Moreover, bass tagged on the Irish coasts have never been caught near English or French coasts (Kennedy \& Fitzmaurice, 1972). Child (1992) detected a degree of substructuring around the coast of Britain and suggested the presence of a separate stock to the south of Ireland on the basis of variation at a single locus (i.e. the enzyme phosphoglucomutase). In sole (Solea solea), Exadactylos et al. (2003) also suggested that Irish, Isle of Man, and Cumbrian samples might be distinct from continental Europe, including Bay of Biscay samples. At a similar geographical scale, low but possibly significant genetic differentiation between sea bass populations from the English Channel and southern North Sea (Antwerp) was already reported by Naciri et al. (1999). Using allozymes, Castilho \& McAndrew (1998) also reported significant local genetic differentiation in sea bass along Portuguese coasts. So, Irish sea bass may constitute a population which could be separated from the other one found in the Celtic Sea. If this hypothesis (which is equally held by the study group of bass (ICES, 2003)) is true, it could explain genetic differences observed 
between the Ireland sample and the other samples. In this case, recapture and genetic data would be in agreement. Moreover, individuals from the Irish sample presented distinct phenotypes from other sea bass, especially the size of scales (S. Loreau, Ecloserie Marine de Gravelines; pers. comm.), that could also suggest possible genetic distinctness of the Ireland sample. Genetic structure was more patchy than previously expected for various species around the British Isles or among British Isles populations and populations from continental Europe, including species of high economic interest such as cod (Hutchinson et al., 2001), and sole (Exadactylos et al., 1998, 2003). Hence, genetic differentiation of sea bass around the British Isles, and in North Sea, should be further documented for better assessment of stock structure.

\section{Conclusions and management implications}

The ICES seabass study group (ICES, 2003) distinguished six unit stocks (Fig. 1). The North Sea and the Irish waters were considered as separate stocks (ICES, 2003). Results pertaining to our study suggest that some of these bass "stocks" may be valid but others not, depending on the method employed. Our tagging study supported the Bay of Biscay as a demographically distinct unit from the English Channel (Fig. 1). Based on the recapture study, it is more difficult to validate or invalidate distinct zones within the English Channel (stocks C, E, F; Fig. 1). Individuals tagged in the English Channel were generally caught in the same stock within the Channel. Genetic results support no stock differentiation between Bay of Biscay and the English Channel, and no differentiation between "stocks" from the English Channel (Table 6). Hence, so much stock delimitation along continental Europe, and especially in the English Channel, is inaccurate from a population genetics point of view. Genetic data integrate long-term patterns (e.g., historical and trans-generational) in the dynamics and dispersal of sea bass stocks, whereas the demographic data considered here are relevant for short-term (e.g. within year, such as dispersal or absence of dispersal after tagging on spawning grounds; Fig. 2) dispersal. In fact, delineation of two stocks - namely Bay of Biscay and the English Channel as a whole - should be sufficient, taking equitably into account the results from both recapture and genetic study. Finally, if the results require further support, independence of the Ireland stock is partly justified both from a genetic point of view (this study), and from recapture data (Kennedy \& Fitzmaurice, 1972; Kelley, 1979).

\section{Acknowledgements}

The mark-recapture study was funded by IFREMER as part of the "Défi Golfe de Gascogne", genetic analysis was performed in UMR CNRS 5171 at Sète. We thank the Oceanic Développement company, all the scientists and fishermen who took part in tagging on pelagic trawlers, and all the fishermen who returned tags from sea bass. We thank S. Loreau at the Ecloserie Marine de Gravelines for precious information. Finally, we are grateful to S. Bermell-Fleury and S. Gros for providing help with figures, and to D. McKenzie for revising the English.

\section{References}

Adams, B.K., Hutchings, J.A., 2003. Microgeographic population structure of brook charr : a comparison of microsatellite and mark-recapture data. J. Fish Biol. 62, 517-533. 
Allegrucci, G., Fortunato, C., Sbordoni, V., 1997. Genetic structure and allozyme variation of sea bass (Dicentrarchus labrax and D. punctatus) in the Mediterranean Sea. Mar. Biol. 128, 347-358.

Bahri-Sfar, L., Lemaire, C., Ben Hassine, O.K., Bonhomme, F., 2000. Fragmentation of sea bass populations in the western and eastern Mediterranean as revealed by microsatellite polymorphism. Proc. R. Soc. Lond., B 267, 929-935.

Belkhir, K., Borsa, P., Chikhi, L., Raufaste, N., Bonhomme, F., 1996-2004. GENETIX 4.05, logiciel sous Windows TM pour la génétique des populations. Laboratoire Génome, Populations, Interactions, CNRS UMR 5171, Université de Montpellier II, Montpellier (France).

Bonhomme, F., Naciri, M., Bahri-Sfar, L., Lemaire, C., 2002. Analyse comparée de la structure génétique de deux espèces de poissons marins apparentées et sympatriques Dicentrarchus labrax et Dicentrarchus punctatus. C. R. Biologies 325, 213-220.

Caccone, A., Allegrucci, G., Fortunato, C., Sbordoni, V., 1997. Genetic differentiation within the European sea bass (․ labrax) as revealed by RAPD-PCR assays. J. Hered. 88, 316-324.

Carvalho, G.R., Hauser, L., 1995. Molecular genetics and the stock concept in fisheries. Chapman and Hall, Inc., London, SE1 8HN, UK., 55-79.

Castilho, R., Mcandrew, B.J., 1998. Population structure of sea bass in Portugal: evidence from allozymes. J. Fish Biol. 53, 1038-1049.

Child, A.R., 1992. Biochemical polymorphism in bass, Dicentrarchus labrax, in the waters around the British Isles. J. Mar. Biol. Ass. UK 72, 357-364.

Chistiakov, D.A., Hellemans, B., Tsigenopoulos, C.S., Law, A.S., Bartley, N., Bertotto, D., Libertini, A., Kotoulas, G., Haley, C.S., Volckaert, F.A.M., 2004. Development and linkage relationships for new microsatellite markers of the sea bass (Dicentrarchus labrax L.). Anim. Genet. 35, 53-57.

Ciftci, Y., Castilho, R., Mcandrew, B.J., 2002. More polymorphic microsatellite markers in the European sea bass (Dicentrarchus labrax L.). Mol. Ecol. Notes 2, 575-576.

Exadactylos, A., Geffen, A.J., Thorpe, J.P., 1998. Population structure of the dover sole, Solea solea L., in a background of high gene flow. J. Sea Res. 40, 117-129.

Exadactylos, A., Geffen, A.J., Panagiotaki, P., Thorpe, J.P., 2003. Population structure of Dover sole Solea solea: RAPD and allozyme data indicate divergence in European stocks. Mar. Ecol. Prog. Ser. 246, 253-264.

Frank, K.T., Brickman, D., 2000. Allee effects and compensatory population dynamics within a stock complex. Can. J. Fish. Aquat. Sci. 57, 513-517. 
Garcia De Leon, F.J., Chikhi, L., Bonhomme, F., 1997. Microsatellite polymorphism and population subdivision in natural populations of European sea bass Dicentrarchus labrax (Linnaeus, 1758). Mol. Ecol. 6, 51-62.

Hauser, L., Ward, R.D., 1998. Population identification in pelagic fish: the limits of molecular markers. In: Carvalho, G.R. (Ed.), Advances in Molecular Ecology. IOS Press, Amsterdam, pp. 191-224.

Holden, M.J., Williams, T., 1974. The biology, movements and population dynamics of bass, Dicentrarchus labrax, in English waters. J. Mar. Biol. Ass. UK 54, 91-107.

Holm, S., 1979. A simple sequentially rejective multiple test procedure. Scand. J. Statist. 6, 65-70.

Hutchinson, W.F., Carvalho, G.R., Rogers, S.I., 2001. Marked genetic structuring in localised spawning populations of cod Gadus morhua in the North Sea and adjoining waters, as revealed by microsatellites. Mar. Ecol. Prog. Ser. 223, 243-250.

ICES, 2002. Report of the study group on sea bass. ICES CM 2002/ACFM : 11 Ref G.

ICES, 2003. Report of the study group on sea bass. ICES CM 2004/ACFM : 04.

ICES, 2004. Report of the study group on sea bass. ICES CM 2005/ACFM : 04 Ref.G.

Kelley, D.F., 1979. Bass populations and movements on the west coast of the U.K.. J. Mar. Biol. Ass. UK 59, 889-936.

Kennedy, M., Fitzmaurice, P., 1972. The biology of the bass, Dicentrarchus labrax, in irish waters. J. Mar. Biol. Ass. UK 53, 557-597.

Leberg, P., 2002. Estimating allelic richness: effects of sample size and bottlenecks. Mol. Ecol. 11, 2445-2449

McQuinn, I.H., 1997. Metapopulations and the Atlantic herring. Rev. Fish Biol. Fish. 7, 297329.

Naciri, M., Lemaire, C., Borsa, P., Bonhomme, F., 1999. Genetic study of the Atlantic/Mediterranean transition in sea bass (Dicentrarchus labrax). J. Hered. 90, 591-596.

Palumbi, S.R., 2004. Marine reserves and ocean neighborhoods: The spatial scale of marine populations and their management. Annu. Rev. Environ. Res. 29, 31-68.

Patarnello, T., Bargelloni, L., Caldara, F., Colombo, L., 1993. Mitochondrial DNA sequence variation in the European sea bass, Dicentrarchus labrax L. (Serranidae): evidence of differential haplotype distribution in natural and farmed populations. Mol. Mar. Biol. Biotechnol. 2, 333-337.

Pawson, M.G., Kelley, D.F., Pickett, G.D., 1987. The distribution and migrations of bass, Dicentrarchus labrax L., in waters around England and Wales as shown by tagging. J. Mar. Biol. Ass. UK 67, 183-217. 
Petit, R. J., El Mousadik, A., Pons, O. 1998. Identifying populations for conservation on the basis of genetic markers. Conserv. Biol .12, 844-855

Pickett, G.D., Pawson, M.G., 1994. Sea bass biology, exploitation and conservation. Chapman et Hall (Ed.), Fish and Fisheries series, London.

Pickett, G.D., Kelley, D.F., Pawson, M.G., 2004. The patterns of recruitment of sea bass, Dicentrarchus labrax L. from nursery areas in England and Wales and implications for fisheries management. Fish. Res. 68, 329-342.

Rousset, F., 2001. Inferences from spatial population genetics. In: Balding, D., Bishop, M., Cannings, C. (Eds.), Handbook of Statistical Genetics. Wiley, Chichester, pp. 239-269.

Slatkin, M., 1985. Gene flow in natural populations. Annu. Rev. Ecol. Syst. 16, 393-430.

Smedbol, R.K., Stephenson, R., 2001. The importance of managing within-species diversity in cod and herring fisheries of the north-western Atlantic. J. Fish Biol. 59, 109-128.

Stephenson, R.L., 1999. Stock complexity in fisheries management: A perspective of emerging issues related to population sub-units. Fish. Res. 43, 247-249.

Vandewoestijne, S., Baguette, M., 2004. Demographic versus genetic dispersal measures. Pop. Ecol. 46, 281-285.

van Oosterhout, C., Hutchinson, W.F., Willis, D.P.M., Shipley, P.F., 2004. Micro-checker : software for identifying and correcting genotyping errors in microsatellite data. Mol. Ecol. Notes 4, 535-538.

Weir, B.S., 1979. Inference about linkage disequilibrium. Biometrics 31, 235-254

Weir, B.S., Cockerham, C.C., 1984. Estimating F-statistics for the analysis of population structure. Evolution 38, 1358-1370.

Wright, S., 1951. The genetical structure of populations. Ann. Eugen. 15, 323-354. 


\section{Tables and figures}

Table 1: Dates of tagging, capture and release locations and number of tagged bass. Several pairs of trawlers took part in tagging campaigns. They are distinguished in the table: 1- Les Menhirs / Le Dolmen; 2- Morgane / Thomas-Nicolas; 3- Pen Kiriac III; 4- Vent de Galerne / Melpomène; 5- Magayant / Jet Stream; 6- Actinie / Ablette; 7- Gaëtan Fabien / Pennaouerez Ar Mor

\begin{tabular}{|c|c|c|c|c|c|}
\hline Area & $\begin{array}{l}\text { Tagging } \\
\text { months }\end{array}$ & $\begin{array}{l}\text { Tagging days } \\
\text { per month }\end{array}$ & $\begin{array}{c}\text { Number } \\
\text { tagged }\end{array}$ & $\begin{array}{l}\text { Capture and Release area } \\
\text { (ICES Statistical Rectangles) }\end{array}$ & $\begin{array}{c}\text { Pair } \\
\text { Trawlers }\end{array}$ \\
\hline \multirow{9}{*}{$\begin{array}{l}\text { English } \\
\text { Channel / } \\
\text { Celtic Sea }\end{array}$} & Mar. 2000 & 6 & 176 & 27E6; 28E6; 29E7; 30E4; 34E4 & 1 \\
\hline & Mar. 2002 & 28 & 861 & 27E6; 28E5; 28E6; 28E7; 29E7; 29E8; 30E4 & $1-2-3$ \\
\hline & Apr. 2002 & 3 & 56 & 27E6; 28E6; 29E3; 29E6; 29E7 & $1-3$ \\
\hline & Feb. 2003 & 14 & 292 & 26E5; 27E4; 27E5; 27E6; 28E5; 28E6 & 1 \\
\hline & Mar. 2003 & 6 & 199 & 27E5; 28E6; 28E7; 29E5; 29E6; 30E5 & $4-5$ \\
\hline & Apr. 2003 & 6 & 131 & $27 \mathrm{E} 7 ; 28 \mathrm{E} 7$ & 5 \\
\hline & Jan. 2004 & 3 & 38 & $28 \mathrm{E} 5$ & 1 \\
\hline & Mar. 2004 & 14 & 392 & 27E5; 27E6; 28E6; 28E8; 29E6; 29E8 & 1 \\
\hline & \multicolumn{2}{|c|}{ Total } & 2137 & & \\
\hline \multirow{10}{*}{$\begin{array}{l}\text { Bay of } \\
\text { Biscay }\end{array}$} & Dec. 2001 & 7 & 238 & 18E8; 19E8; 20E8 & 6 \\
\hline & Jan. 2002 & 11 & 457 & 19E8; 20E7; 21E7 & 6 \\
\hline & Dec. 2002 & 4 & 57 & $21 \mathrm{E} 7$ & 6 \\
\hline & Jan. 2003 & 20 & 803 & $21 \mathrm{E} 7$ & 6 \\
\hline & Feb. 2003 & 21 & 1,096 & 21E6; 21E7 & $6-7$ \\
\hline & Mar. 2003 & 16 & 576 & 18E8; 19E7; 19E8; 20E6; 20E7; 21E7 & $6-7-4$ \\
\hline & Dec. 2003 & 10 & 146 & 21E7; 22E6; 22E7 & $6-4$ \\
\hline & Jan. 2004 & 13 & 490 & $21 \mathrm{E} 7$ & 6 \\
\hline & Feb. 2004 & 5 & 124 & $21 \mathrm{E} 7$ & 6 \\
\hline & \multicolumn{2}{|c|}{ Total } & 3977 & & \\
\hline
\end{tabular}


Table 2: Details of samples used in genetic analysis

\begin{tabular}{|c|c|c|c|c|c|c|}
\hline & Sample & Origin & Area & Age & Date & Number \\
\hline 1 & Scotland & Oceanographic ship & West of the Scottish coasts & \multirow{4}{*}{ Adults } & 2000 & 17 \\
\hline 2 & Ireland & Oceanographic ship & West of the Celtic Sea & & 2000 & 18 \\
\hline 3 & West Channel & Commercial trawler & ICES Division VIIe & & Apr. 2003 & 31 \\
\hline 4 & Bay of Biscay & Commercial trawler & ICES Division VIIIb & & Feb. 2003 & 95 \\
\hline 5 & Calais & Recreational anglers & Calais Beach & \multirow{4}{*}{ Juveniles } & Oct. 2002 & 51 \\
\hline 6 & Saint-Malo & Fixed fishing lot (vérif) & Mont-Saint-Michel Bay & & Nov. 2002 & 116 \\
\hline 7 & La Rochelle & Musée océanographique & ICES Stat. Rect. 21E8 & & Dec. 2002 & 53 \\
\hline 8 & Biarritz & Musée de la Mer & ICES Stat. Rect.. 16E8 & & June 2003 & 50 \\
\hline
\end{tabular}


Table 3: Primers used in this study. Name of the fluorochrome, annealing temperature, and duration of annealing cycles are given for each locus. * Tsigenopoulos et al., 2003; ** Chistiakov et al., 2004; *** Cifti et al., 2002

\begin{tabular}{|c|c|c|c|c|c|}
\hline \multirow{2}{*}{ Locus } & \multicolumn{2}{|c|}{ Primers (5’-3’) } & \multirow{2}{*}{$\begin{array}{l}\text { Fluoro- } \\
\text { chrome }\end{array}$} & \multicolumn{2}{|c|}{ Annealing } \\
\hline & forward & reverse & & $\mathrm{T}^{\circ} \mathrm{C}$ & Time \\
\hline DLA0001* & GATGGCTGTCTGTTTTCCTAAC & GAGTGTCCTTGTATCCGTTTTG & 6-fam & 58 & $1^{\prime}$ \\
\hline DLA0003* & GGACCAAATGCAAAAGCTACA & GACAATCAGCTGGGATCAGA & Tamra & 58 & $40^{\prime \prime}$ \\
\hline DLA0004* & TCCTTCCGTGAACTGAGAGC & TCTTCCACCATAGGCTGACC & 6-fam & 58 & $40^{\prime \prime}$ \\
\hline DLA0006* & TTCCATATTGTATGACACACCG & GAGTCCTGCAAGACAATCCC & 6-fam & 55 & 1 ' \\
\hline DLA0011* & TCGGAGCTGATATTGTGCAG & CTGTCTGTCCTCCCCATTGT & Tamra & 56 & $45^{\prime \prime}$ \\
\hline DLA0107** & GAGGCTGTATGCTGTTGCAG & ACCCATGCATAAGGTCAGTG & 6-fam & 54 & $45^{\prime \prime}$ \\
\hline DLA0111** & TCACAAAATGATCCATCTTCT & ACCACTATGCCCAAGGACAA & Tamra & 56 & $45^{\prime \prime}$ \\
\hline Dla-47*** & CGGATGAAACCAGTAGTTCC & AGTTCTTAGACAGAGCGAGG & 6-fam & 57 & $1^{\prime}$ \\
\hline
\end{tabular}


Table 4: Release positions, numbers of bass tagged in winter offshore fisheries on the spawning grounds, and numbers of recaptures from these tagged locations. Tagging and recapture can take place the same year (column "year n”) or have at least one year difference (column "year >n”). Numbers in brackets indicate rates of recapture per year and per ICES divisions

\begin{tabular}{|c|c|c|c|c|c|c|}
\hline \multirow{2}{*}{ Area } & \multirow{2}{*}{\multicolumn{2}{|c|}{$\begin{array}{l}\text { Tagging ICES Divisions and } \\
\text { ICES Statisticals Rectangles }\end{array}$}} & \multirow{2}{*}{$\begin{array}{l}\text { Tagging } \\
\text { Year }\end{array}$} & \multirow{2}{*}{$\begin{array}{c}\text { Number } \\
\text { tagged }\end{array}$} & \multicolumn{2}{|c|}{ Recapture } \\
\hline & & & & & year $n$ & year $>n$ \\
\hline \multirow{12}{*}{$\begin{array}{c}\text { English } \\
\text { Channel / } \\
\text { Celtic Sea }\end{array}$} & VII a & $34 \mathrm{E} 4$ & 2000 & 17 & & \\
\hline & \multirow{2}{*}{ VII d } & 29E8 & 2002 & 13 & & \\
\hline & & 28E8; 29E8 & 2004 & 60 & & \\
\hline & \multirow{4}{*}{ VII e } & 27E6; 28E6; 29E7 & 2000 & 111 & & \\
\hline & & $\begin{array}{c}\text { 27E6; 28E5; 28E6; 28E7; } \\
\text { 29E5; 29E6; 29E7 }\end{array}$ & 2002 & 799 & $7(0.9)$ & \\
\hline & & $\begin{array}{l}\text { 26E5; 27E5; 27E6; 27E7; 28E5; } \\
\text { 28E6; 28E7; 29E5; 29E6 }\end{array}$ & 2003 & 609 & $12(2.0)$ & $2(0.3)$ \\
\hline & & 27E5; 27E6; 28E5; 28E6; 29E6 & 2004 & 370 & $3(0.8)$ & \\
\hline & \multirow{3}{*}{ VII f } & $30 \mathrm{E} 4$ & 2000 & 48 & $1(2.1)$ & \\
\hline & & 29E3; 30E4 & 2002 & 97 & & \\
\hline & & 30E5 & 2003 & 7 & & \\
\hline & VII h & 27E4 & 2003 & 6 & & \\
\hline & & Total & & 2137 & $23(1.1)$ & $2(0.1)$ \\
\hline \multirow{7}{*}{$\begin{array}{l}\text { Bay of } \\
\text { Biscay }\end{array}$} & \multirow{3}{*}{ VIII a } & $21 \mathrm{E} 7$ & 2002 & 463 & & \\
\hline & & 21E6; 21E7; 22E6; 22E7 & 2003 & 2295 & $20(0.9)$ & $2(0.01)$ \\
\hline & & $21 \mathrm{E} 7$ & 2004 & 610 & $5(0.8)$ & $1(0.2)$ \\
\hline & \multirow{3}{*}{ VIII b } & 18E8; 19E8; 20E8 & 2001 & 238 & $2(0.8)$ & $8(3.4)$ \\
\hline & & 19E8; 20E7 & 2002 & 51 & $1(2.0)$ & \\
\hline & & 18E8; 19E7; 19E8; 20E6; 20E7 & 2003 & 320 & $5(1.6)$ & \\
\hline & & $\begin{array}{c}\text { Total } \\
\end{array}$ & & 3977 & $33(0.8)$ & $11(0.3)$ \\
\hline \multicolumn{2}{|c|}{ Total } & 6114 sea bass tagged & & & $56(0.9)$ & $13(0.2)$ \\
\hline
\end{tabular}




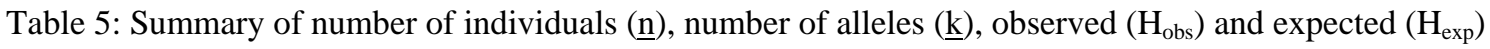
heterozygosities, and $\underline{\mathrm{f}}$ per locus and per population. Total observed number of alleles per locus $\left(\mathrm{K}_{\mathrm{tot}}\right)$, standardised allelic richness $\left(\underline{k}_{\text {est }}\right)$ per locus and per sample according to Petit et al. (1998) (standardisation according to the lowest sample size $\underline{n}$; i.e. Scotland or West Channel sample depending on loci; as standardisation was not the same over loci and samples when the Ireland and Scotland samples were included, no average values over population or loci were computed for $\left.\underline{\mathrm{k}}_{\mathrm{est}}\right)$, and average $\underline{\mathrm{f}}$ per population are also indicated. Averages of $\underline{k}_{\text {est }}$ were not computed as standardisation was not identical over loci. Significant values after Bonferroni correction are indicated by * $(\mathrm{p}<0.05)$, ** $(\mathrm{p}<0.01)$ or *** $(\mathrm{p}<0.001)$.

\begin{tabular}{|c|c|c|c|c|c|c|c|c|c|}
\hline & & Bay of Biscay & La Rochelle & Biarritz & West Channel & Calais & Saint-Malo & Ireland & Scotland \\
\hline \multirow{6}{*}{$\begin{array}{c}\text { DLA0001 } \\
\mathrm{K}_{\text {tot }}=14\end{array}$} & $\mathrm{n}$ & 95 & 53 & 50 & 31 & 51 & 113 & 18 & 17 \\
\hline & $\mathrm{k}$ & 9 & 8 & 9 & 7 & 9 & 14 & 8 & 4 \\
\hline & $\mathrm{k}_{\mathrm{est}}$ & 5.9 & 6.1 & 6.3 & 5.1 & 6.2 & 6.7 & 5.0 & 3.2 \\
\hline & Неxp & 0.702 & 0.730 & 0.772 & 0.684 & 0.678 & 0.743 & 0.660 & 0.521 \\
\hline & Hobs & 0.653 & 0.623 & 0.740 & 0.581 & 0.706 & 0.673 & 0.500 & 0.529 \\
\hline & $\mathrm{f}$ & 0.071 & 0.149 & 0.042 & 0.153 & -0.042 & 0.095 & 0.248 & -0.018 \\
\hline \multirow{6}{*}{$\begin{array}{l}\text { DLA0003 } \\
\mathrm{K}_{\text {tot }}=27\end{array}$} & $\mathrm{n}$ & 95 & 51 & 50 & 31 & 51 & 115 & & \\
\hline & $\mathrm{k}$ & 25 & 19 & 18 & 16 & 19 & 20 & & \\
\hline & $\mathrm{k}_{\mathrm{est}}$ & 14.7 & 15.6 & 15.5 & 13.0 & 15.7 & 13.1 & & \\
\hline & Неxp & 0.925 & 0.916 & 0.924 & 0.928 & 0.907 & 0.916 & & \\
\hline & Hobs & 0.947 & 0.961 & 0.940 & 0.871 & 0.902 & 0.930 & & \\
\hline & $\mathrm{f}$ & -0.025 & -0.049 & -0.018 & 0.062 & 0.006 & -0.016 & & \\
\hline \multirow{6}{*}{$\begin{array}{c}\text { DLA0004 } \\
\mathrm{K}_{\mathrm{tot}}=18\end{array}$} & $\mathrm{n}$ & 95 & 53 & 50 & 31 & 50 & 116 & & \\
\hline & $\mathrm{k}$ & 15 & 14 & 14 & 11 & 13 & 16 & & \\
\hline & $\mathrm{k}_{\mathrm{est}}$ & 8.6 & 7.8 & 8.2 & 8.1 & 8.4 & 8.9 & & \\
\hline & Неxp & 0.888 & 0.883 & 0.860 & 0.844 & 0.866 & 0.873 & & \\
\hline & Hobs & 0.905 & 0.830 & 0.860 & 0.903 & 0.900 & 0.853 & & \\
\hline & $\mathrm{f}$ & -0.019 & 0.060 & 0.000 & -0.072 & -0.040 & 0.022 & & \\
\hline \multirow{6}{*}{$\begin{array}{c}\text { DLA0006 } \\
\mathrm{K}_{\mathrm{tot}}=13\end{array}$} & $\mathrm{n}$ & 95 & 49 & 50 & 31 & 50 & 116 & & \\
\hline & $\mathrm{k}$ & 11 & 8 & 8 & 9 & 9 & 11 & & \\
\hline & $\mathrm{k}_{\mathrm{est}}$ & 7.3 & 7.7 & 7.7 & 7.4 & 7.9 & 7.5 & & \\
\hline & Неxp & 0.673 & 0.528 & 0.582 & 0.533 & 0.617 & 0.610 & & \\
\hline & Hobs & 0.568 & 0.490 & 0.360 & 0.355 & 0.260 & 0.491 & & \\
\hline & $\mathrm{f}$ & $0.156 *$ & 0.073 & $0.383 * * *$ & $0.338 * *$ & $0.581 * * *$ & $0.195 * *$ & & \\
\hline \multirow{6}{*}{$\begin{array}{c}\text { DLA0011 } \\
\mathrm{K}_{\mathrm{tot}}=28\end{array}$} & $\mathrm{n}$ & 90 & 49 & 50 & 30 & 45 & 106 & 18 & 17 \\
\hline & $\mathrm{k}$ & 24 & 25 & 23 & 17 & 21 & 23 & 16 & 15 \\
\hline & $\mathrm{k}_{\mathrm{est}}$ & 14.4 & 13.8 & 13.6 & 12.5 & 13.9 & 14.2 & 8.8 & 8.3 \\
\hline & $\mathrm{He}$ & 0.949 & 0.947 & 0.939 & 0.928 & 0.939 & 0.942 & 0.941 & 0.939 \\
\hline & Hobs & 0.944 & 0.959 & 0.920 & 0.833 & 0.889 & 0.934 & 1.000 & 0.941 \\
\hline & $\mathrm{f}$ & 0.005 & -0.013 & 0.020 & 0.104 & 0.054 & 0.008 & $-0.064 * * *$ & -0.002 \\
\hline \multirow{6}{*}{$\begin{array}{l}\text { DLA0107 } \\
\mathrm{K}_{\mathrm{tot}}=19\end{array}$} & $\mathrm{n}$ & 92 & 45 & 50 & 31 & 45 & 114 & 18 & 17 \\
\hline & $\mathrm{k}$ & 16 & 14 & 14 & 15 & 12 & 16 & 10 & 11 \\
\hline & $\mathrm{k}_{\mathrm{est}}$ & 8.2 & 7.0 & 6.8 & 6.8 & 6.4 & 7.5 & 6.3 & 5.3 \\
\hline & Неxp & 0.872 & 0.847 & 0.878 & 0.891 & 0.857 & 0.857 & 0.875 & 0.895 \\
\hline & Hobs & 0.783 & 0.800 & 0.900 & 0.936 & 0.867 & 0.816 & 0.889 & 0.941 \\
\hline & $\mathrm{f}$ & 0.103 & 0.056 & -0.025 & -0.051 & -0.011 & 0.049 & -0.017 & -0.053 \\
\hline \multirow{6}{*}{$\begin{array}{c}\text { DLA0111 } \\
\mathrm{K}_{\mathrm{tot}}=14\end{array}$} & $\mathrm{n}$ & 94 & 52 & 50 & 31 & 50 & 115 & 18 & 17 \\
\hline & $\mathrm{k}$ & 12 & 10 & 11 & 11 & 11 & 13 & 7 & 6 \\
\hline & $\mathrm{k}_{\mathrm{est}}$ & 4.6 & 4.7 & 4.2 & 4.3 & 4.4 & 5.1 & 4.0 & 3.9 \\
\hline & Неxp & 0.837 & 0.853 & 0.870 & 0.856 & 0.853 & 0.854 & 0.711 & 0.800 \\
\hline & Hobs & 0.883 & 0.962 & 0.960 & 1.000 & 0.860 & 0.887 & 0.778 & 0.882 \\
\hline & $\mathrm{f}$ & -0.056 & $-0.129 *$ & -0.105 & $-0.172 * * *$ & -0.008 & -0.039 & -0.097 & -0.106 \\
\hline \multirow{6}{*}{$\begin{array}{l}\text { Dla-47 } \\
\mathrm{K}_{\mathrm{tot}}=7\end{array}$} & $\mathrm{n}$ & 95 & 53 & 50 & 31 & 51 & 115 & 18 & 17 \\
\hline & $\mathrm{k}$ & 7 & 6 & 6 & 6 & 6 & 6 & 5 & 7 \\
\hline & $\mathrm{k}_{\mathrm{est}}$ & 3.9 & 3.5 & 3.6 & 3.3 & 3.6 & 3.9 & 3.2 & 3.4 \\
\hline & Неxp & 0.660 & 0.710 & 0.694 & 0.700 & 0.629 & 0.685 & 0.571 & 0.595 \\
\hline & Hobs & 0.684 & 0.755 & 0.640 & 0.710 & 0.628 & 0.678 & 0.556 & 0.471 \\
\hline & $\mathrm{f}$ & -0.037 & -0.064 & 0.078 & -0.015 & 0.003 & 0.010 & 0.029 & 0.215 \\
\hline \multicolumn{2}{|c|}{ Mean Hobs } & 0.796 & 0.798 & 0.790 & 0.774 & 0.752 & 0.783 & 0.745 & 0.753 \\
\hline \multicolumn{2}{|c|}{ Mean $\mathrm{f}$} & 0.021 & 0.006 & 0.031 & 0.028 & 0.053 & 0.033 & 0.010 & -0.004 \\
\hline
\end{tabular}


Table 6: Genetic structuring in sampled populations of the English Channel and the Bay of Biscay screened for eight loci. Significant pairwise $\underline{\underline{F}}_{\text {st }}$ value without correction for multiple tests is indicated by * $(\mathrm{p}<0.05)$.

\begin{tabular}{lcccccc}
\hline & Bay of Biscay & La Rochelle & Biarritz & West Channel & Calais & Saint-Malo \\
\hline Bay of Biscay & - & 0.0002 & 0.0021 & 0.0028 & -0.0006 & 0.0008 \\
\hline La Rochelle & - & 0.0007 & 0.0017 & 0.0001 & -0.0002 \\
\hline Biarritz & & - & -0.0002 & 0.0031 & -0.0011 \\
\hline West Channel & & & & - & -0.0008 & $0.0048^{*}$ \\
\hline \multicolumn{1}{r}{ Calais } & & & & & - & 0.0022 \\
\hline
\end{tabular}


Table 7: Genetic structuring in all sampled populations screened for five loci. Significant pairwise $\underline{\mathrm{F}}_{\mathrm{st}}$ value without correction for multiple tests is indicated by $*(\mathrm{p}<0.05)$ or $* *(\mathrm{p}<$ $0.01)$.

\begin{tabular}{|c|c|c|c|c|c|c|c|c|}
\hline & Bay of Biscay & La Rochelle & Biarritz & West Channel & Calais & Saint-Malo & Ireland & Scotland \\
\hline Bay of Biscay & - & -0.0017 & 0.0018 & -0.0012 & 0.0001 & 0.0014 & 0.0099* & 0.0015 \\
\hline La Rochelle & & - & 0.0006 & 0.0007 & 0.0002 & -0.0007 & $0.0146 *$ & 0.0083 \\
\hline Biarritz & & & - & 0.0020 & $0.0052 *$ & -0.0024 & $0.0159 * *$ & $0.0109 *$ \\
\hline West Channel & & & & - & -0.0033 & 0.0028 & $0.0116 *$ & 0.0034 \\
\hline Calais & & & & & - & 0.0041 & 0.0047 & -0.0011 \\
\hline Saint-Malo & & & & & & - & $0.0113^{*}$ & $0.0120 *$ \\
\hline Ireland & & & & & & & - & 0.0058 \\
\hline
\end{tabular}




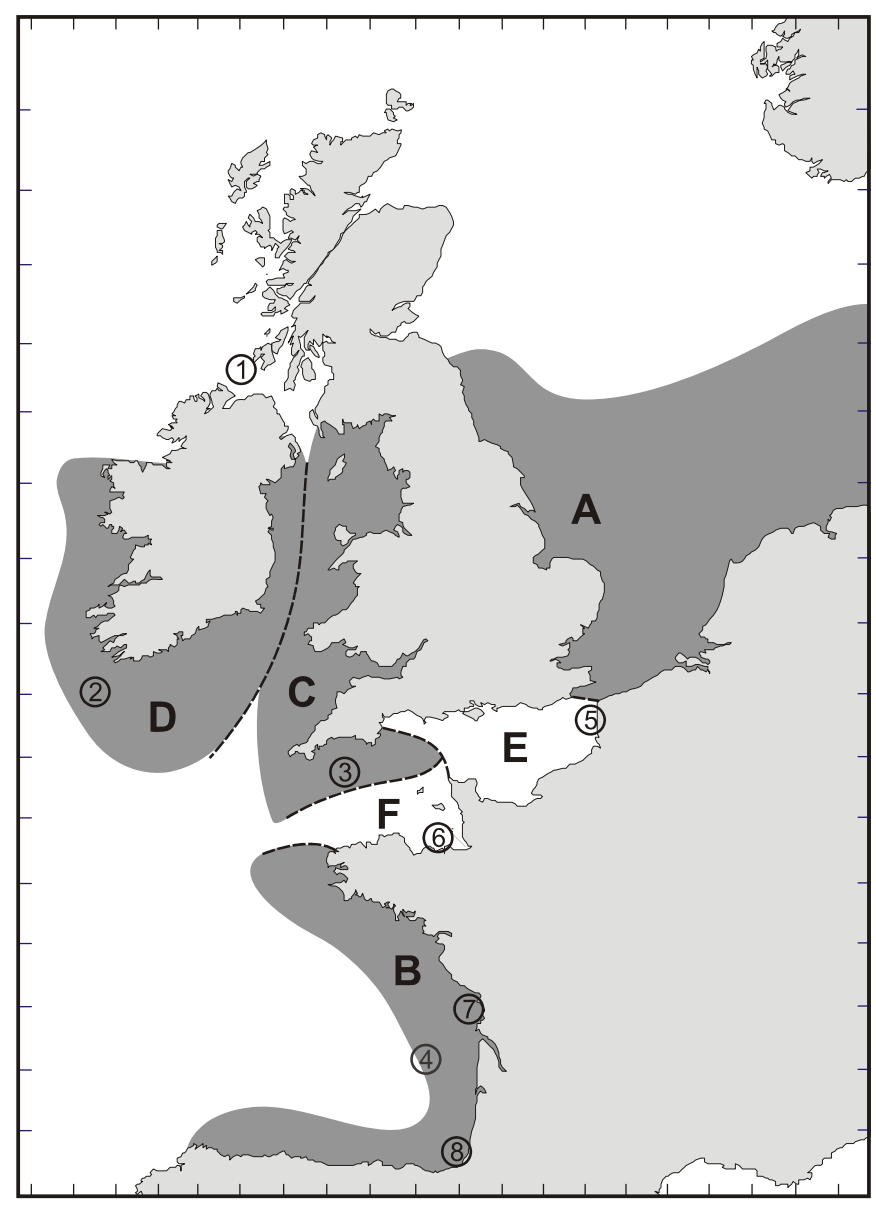

Figure 1 : Recognized “stocks" for sea bass management along Western European Atlantic coastlines (A to F; ICES 2003). Locations of samples used for genetic analyses are indicated by circled numbers (see Tab. 2 for details). 


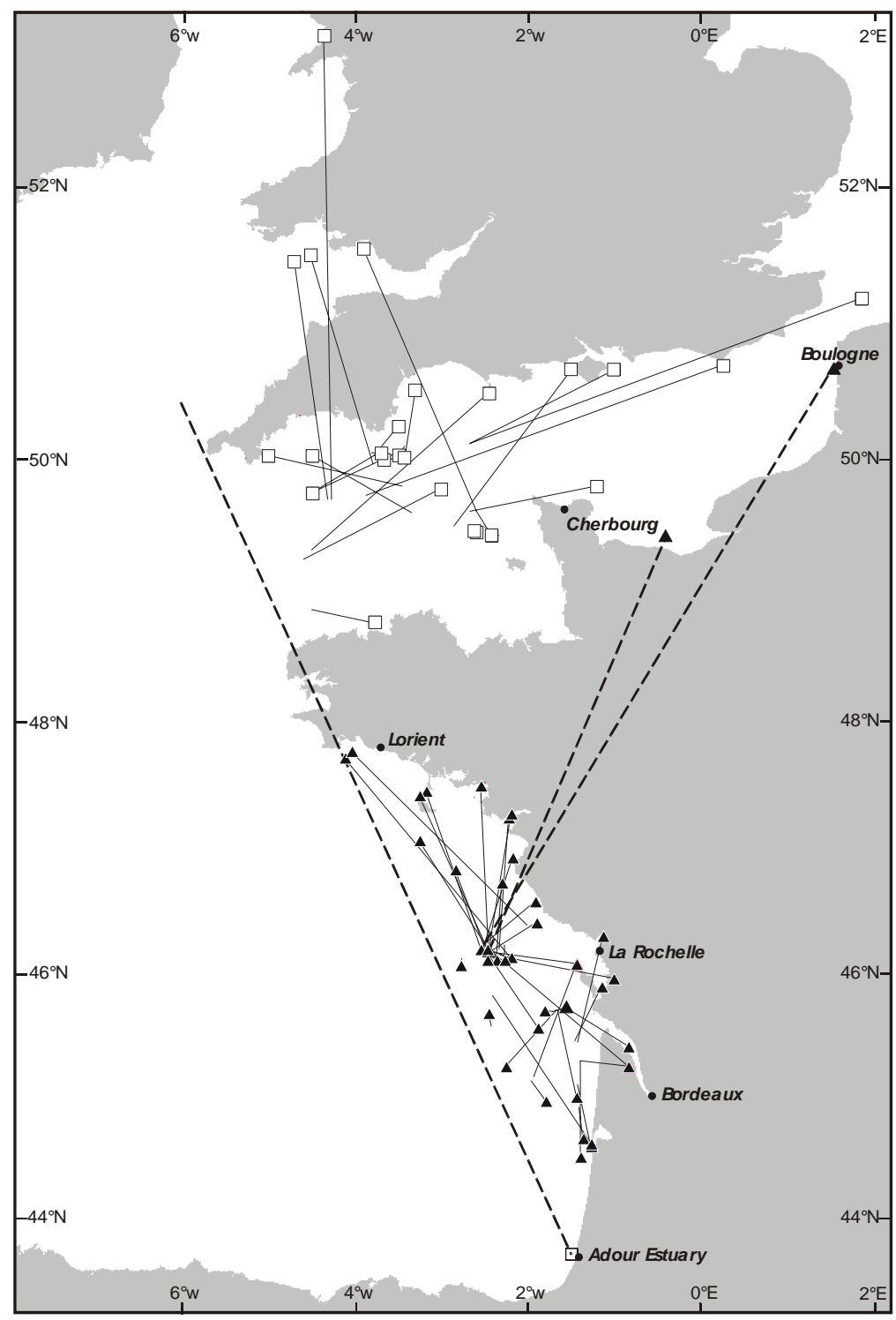

Figure 2: Recaptures of bass tagged in the English Channel or in the Celtic Sea ( $\square$ ) and in the Bay of Biscay ( $\mathbf{\Delta})$. Distance between position of tagging and position of recapture is indicated by a continuous line (-). The three individuals that were recaptured outside the basin where they were tagged are indicated by a discontinuous line (- -). 


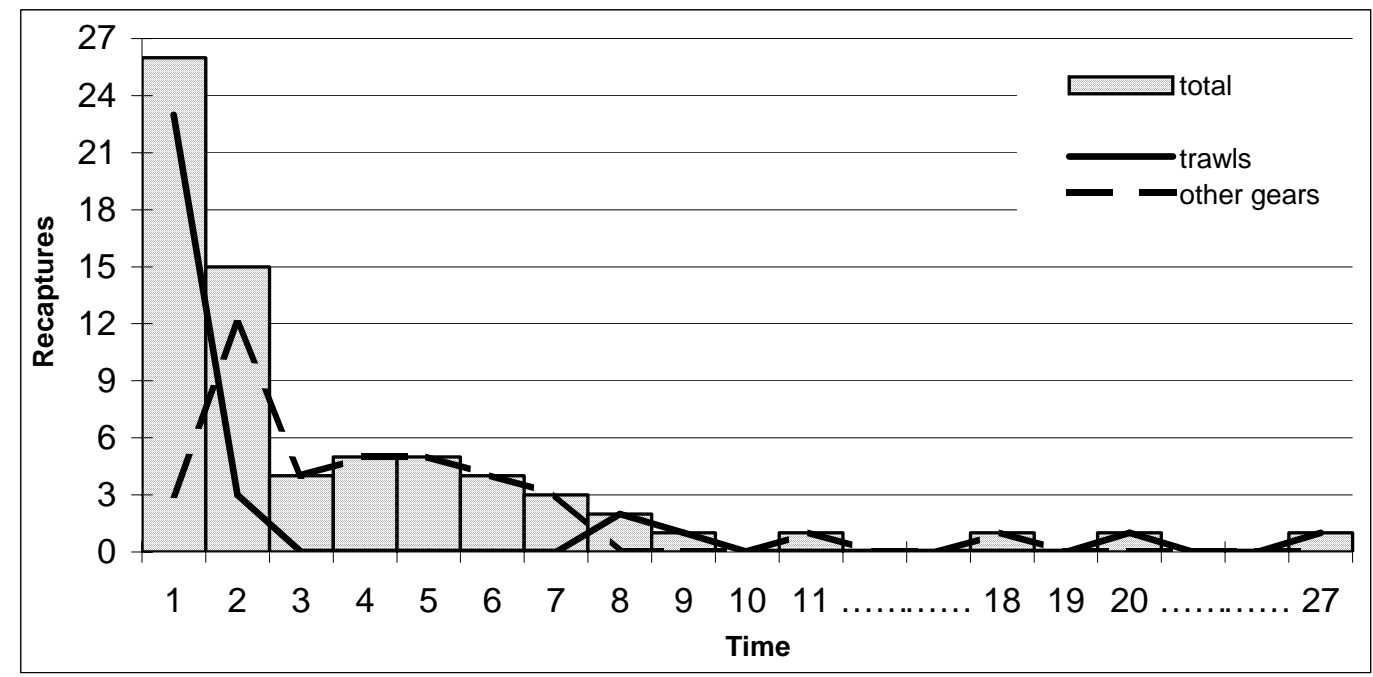

Figure 3: Number of recaptures over time (in months) following tagging. 